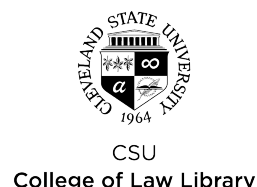

Cleveland State University

College of Law Library

\title{
EngagedScholarship@CSU
}

$1-15-2016$

\section{'Fire Away': I Have No Right to Not Be Insulted}

David R. Barnhizer

Cleveland State University, d.barnhizer@csuohio.edu

Follow this and additional works at: https://engagedscholarship.csuohio.edu/fac_articles

Part of the Higher Education Commons, and the Law Commons

How does access to this work benefit you? Let us know!

\section{Repository Citation}

Barnhizer, David R., "'Fire Away': I Have No Right to Not Be Insulted" (2016). Law Faculty Articles and Essays. 824.

https://engagedscholarship.csuohio.edu/fac_articles/824

This Article is brought to you for free and open access by the Faculty Scholarship at EngagedScholarship@CSU. It has been accepted for inclusion in Law Faculty Articles and Essays by an authorized administrator of EngagedScholarship@CSU. For more information, please contact research.services@law.csuohio.edu. 


\title{
CLEVELAND-MARSHALL COLLEGE OF LAW
}

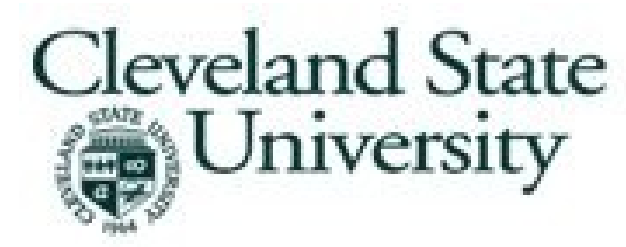

Research Paper 16-290

January 2016

\section{"FIRE Away": I Have No Right to Not Be Insulted \\ by}

\section{David Barnhizer}

\author{
Professor Emeritus of Law, Cleveland-Marshall College of Law
}

Working Paper

This paper can be downloaded without charge from the Social Science Research Network electronic library: 


\section{"FIRE Away": I Have No Right to Not Be Insulted}

\section{David Barnhizer}

FIRE [the Foundation for Individual Rights in Education] is committed to an agenda of challenging the numerous efforts that intentionally or consequentially act as barriers to open discourse on US campuses. ${ }^{1}$ In its Guide to Free Speech on Campus FIRE writes:

Unfortunately, ironically, and sadly, America's colleges and universities are all too often dedicated more to censorship and indoctrination than to freedom and individual self-government. In order to protect "diversity" and to ensure "tolerance," university officials proclaim, views deemed hostile or offensive to some students and some persuasions (and, indeed, some administrators) are properly subjected to censorship under campus codes. ${ }^{2}$

We have long assumed that universities are the institutions that are most responsible for advancing our freedom of thought and discourse through the work of independent scholars and the teaching of each generation of students. But for several decades, universities and other educational institutions have increasingly set up rules aimed at protecting individuals and groups from criticism that those newly empowered individuals and groups consider insensitive, offensive, harassing, intolerant and disrespectful, or critical of their core belief systems. Even though it has been claimed that disadvantaged interest groups have a right to use one-sided tactics of intolerance against those they consider to be responsible for their misfortunes, in a democracy this is a fundamentally wrong policy that ultimately tears apart the social fabric.

The speech suppression and intimidation movement goes far beyond university campuses, although since those institutions are the vehicles by which we educate our leaders and policy makers it is fair to assert that such intellectual paragons generate substantial influence over what is considered appropriate and desirable. The problem penetrates

\footnotetext{
${ }^{1}$ FIRE's Guide to Free Speech on Campus can be found at https://www.thefire.org/fire-guides/fires-guide-to-freespeech-on-campus-3/.

${ }^{2}$ FIRE, Guide to Free Speech on Campus, at 4, 5.
} 
considerably deeper into our overall society than simply being prevalent in the behavior of our educational institutions and university teachers, the significant majority of which are drawn from a pool of people with similar beliefs and allegiances. It operates on the levels of our basic social order because the powerful public and private institutions that dominate our culture want obedience far more than challenge, criticism and dissonance. ${ }^{3}$ Honesty requires the admission that we want "mules" much more than serious critics engaged in exposing the "Naked Emperor".

\section{“They Simply Wanted Me to be Silenced!"}

Ayaan Hirsi Ali, born in Somalia and raised in the Muslim faith is a global leader in objecting to such things as the subjugation of women and genital mutilation of young girls. She recently found herself disinvited from speaking at Brandeis University due to her criticisms of Islam. In a similarly repressive incident faculty and student objections related to her participation in the Bush administration resulted in Condoleeza Rice withdrawing as a commencement speaker at Rutgers. Hirsi Ali commented on Brandeis's action, "they simply wanted me to be silenced" in in describing her sense of the motivations of Brandeis officials. ${ }^{4}$ It is interesting to note that Hirsi Ali is the subject of a death fatwa for criticisms she made while living in the Netherlands and as a member of the Dutch Parliament. ${ }^{5}$ She now must have a security detail check out the venues where she will speak. In an outrageously paradoxical and darkly ironic vein one Imam who called for her death due on her criticisms of Islam has been hired by the Department of Justice to teach US prison inmates. ${ }^{6}$

\footnotetext{
${ }^{3}$ A brilliant work on how this theme was authored by French philosopher Jacques Ellul in his The Technological Society and analysis of how the large institutions are technique and use technique to control how and why we act.

${ }^{4}$ http://time.com/56111/ayaan-hirsi-ali-they-simply-wanted-me-to-be-silenced/.

${ }^{5}$ For more on Hirsi Ali's odyssey, see “Ayaan Hirsi Ali: Why are Muslims so 'Hypersensitive’? http://www.theguardian.com/world/2010/may/08/ayaan-hirsi-ali-interview.

${ }^{6}$ One report on this development states: “An Egyptian-born imam who in 2007 said that Somali-born activist Ayaan Hirsi Ali should receive the death penalty for her criticism of Islam is now a Department of Justice contractor hired to teach classes to Muslims who are in federal prison. According to federal spending records, Fouad ElBayly, the imam at Islamic Center of Johnstown in Pennsylvania, was contracted by the DOJ's Bureau of Prisons beginning last year to teach the classes to Muslim inmates at Cumberland Federal Correctional Institution in Cumberland,
} 
The fact that modern-day Brandeis officials, faculty and students acted in this way must have Justice Louis D. Brandeis, a strong advocate of free speech, turning over in his grave. It is reasonable to ask why Justice Brandeis, the first Jewish member of the Supreme Court and the spiritual force behind the creation of Brandeis University, felt so strongly about the importance of free speech. We can begin with his belief that as an ideal, free speech provides benefits that facilitate an individual's development and participation in democratic society. The social benefits of informed discourse are largely indirect, i.e., that a society comprised of "developed" humans is a qualitatively richer society than a society with a bunch of ignorant and unthinking "dummies".

This advances the idea represented by Aristotle's idea of eudaimonia, or human flourishing, where a primary function of the State was to create the conditions conducive to the goal of the maximum qualitative development of individual humans. The understanding was that a community of the most progressive individuals who were seeking to attain their highest potential as humans would create the best community. ${ }^{7}$ This principle is reflected in the words of Justice Brandeis, concurring in Whitney v. California.

Those who won our independence believed that the final end of the State was to make men free to develop their faculties; and that in its government the deliberative forces should prevail over the arbitrary. They valued liberty both as an end and as a means. They believed liberty to be the secret of happiness and courage to be the secret of liberty. They believed that freedom to think as you will and to speak as you think are means indispensable to the discovery and spread of

Md.” http://dailycaller.com/2015/03/03/imam-who-said-ayaana-hirsi-ali-deserved-death-penalty-was-hired-by-dojto-teach-muslim-classes-to-federal-prisoners/\#ixzz3nzgyxBg1.

${ }^{7}$ See, Aristotle, Nichomachean Ethics, c. VII, Bk. I for his description of eudaimonia or human flourishing. One scholar sums it up as: “Aristotle teaches that each man's life has a purpose and that the function of one's life is to attain that purpose. He explains that the purpose of life is earthly happiness or flourishing that can be achieved via reason and the acquisition of virtue. Articulating an explicit and clear understanding of the end toward which a person's life aims, Aristotle states that each human being should use his abilities to their fullest potential and should obtain happiness and enjoyment through the exercise of his realized capacities. He contends that human achievements are animated by purpose and autonomy and that people should take pride in being excellent at what they do. According to Aristotle, human beings have a natural desire and capacity to know and understand the truth, to pursue moral excellence, and to instantiate their ideals in the world through action." See, Edward W. Younkins, "Aristotle: Ayn Rand's Acknowledged Teacher," The Autonomist, http://usabig.com/autonomist/articles/aristotle.html. 8/24/05. 
political truth; that without free speech and assembly discussion would be futile.... ${ }^{8}$

Justice Brandeis's words compel us to confront the core of our dilemma. How on earth can the ideal voiced by Justice Brandeis be harmonized with the intolerant bigotry of a university bearing his name as it succumbs to ideological pressure and cancels its invitation to Hirsi Ali? This is particularly so when Hirsi Ali is a major voice attempting to offer insights in relation to one of the most fundamental challenges we now face-that of the clash of radically different belief systems represented by a host of aggressive and violent extremists of the Islamic faith and those who believe deeply in the Western version of the Rule of Law. Nor is it a conflict between religious perspectives as opposed to a different approach to the role of religion in society.

Ours is now, and if we are honest we should admit it always has been to some degree, a culture in which positions are too often taken and held regardless of evidence. Critics of the favored positions are attacked with contempt and propaganda. Consider, for example, the unfortunate episode involving former Harvard President Lawrence Summers' comments on possible differences in scientific ability between men and women. For weeks afterward there were numerous well-organized calls for his firing. But for the responsible critic it is only fair to review the entire presentation before lynching Larry Summers because his presentation was much more balanced than its critics' analyses. Summers subsequently apologized if he offended anyone, even though it is almost impossible to avoid offending someone when attempting to speak about any issue of consequence in what has become a highly contentious society. ${ }^{9}$

An example of the impossibility of avoiding giving someone real or feigned offense is found in the recent behavior of Clemson University. Its food service department hosted its annual "Maximum Mexican" day in which the food served was oriented to Mexican staples and at

\footnotetext{
${ }^{8}$ Whitney v. California, 274 U.S. 357 (1927).

${ }^{9} \mathrm{See}$, "Remarks at NBER Conference on Diversifying the Science \& Engineering Workforce," Lawrence H. Summers, Cambridge, Mass., January 14, 2005. A telling critique of such criticisms is found in Charles Murray, "The Inequality Taboo," Commentary, September 2005, http://www.commentarymagazine.com/article.asp?aid=12002015_1 (visited 9/5/05). See also, Harvey Mansfield, "Fear and Intimidation at Harvard: What do academic women want?", The Weekly Standard, March 7, 2005, v. 10, Issue 23.
} 
least one of its servers wore a sombrero. Clemson apologized to what appears to be two students "outraged" at the "cultural insensitivity" of such an activity. The university officials apologized and decided not to stage in the future what had been an enjoyable dietary experience for many of the Clemson students who apparently did not understand that by eating tacos and burritos they were "disrespecting" Mexican culture. ${ }^{10}$ One must wonder if the same students are planning on launching a boycott and a financial divestment protest against Clemson if it is discovered the university holds any stock in Taco Bell or Chipotle.

We also must ask whether in a country as vast and diverse as Mexico how it is that a very small sample of students who possess Mexican backgrounds could presume to speak for all Mexicans of all the ethnic and cultural backgrounds represented in that nation's population. This does not even begin to touch on the issue of the nature of Mexican culture as it has developed in the US, a culture that inevitably is not the same as Mexican culture in that nation or the various diverse cultural elements found in Mexico. The implied claim that the "outraged" students are entitled to speak for all Mexican culture has to be viewed as bogus and arrogant. This is a serious problem with the numerous instances in which claims of outrage are being made.

I believe that many of the outraged reactions to speakers' phrasing in many areas where "outrage" is voiced are insincere and done primarily or exclusively for purposes of gaining political advantage. This "fake offensiveness"-- "OMG I am so hurt and offended"--occurs because it is the ammunition by which interest groups gain political advantage. Yet universities, our supposed hotbeds of free and critical thinking, are co-conspirators in suppressing the intellectual independence and discussions they are supposed to be instilling in their students.

\footnotetext{
10 Peter Hasson, “Clemson University apologizes for serving Mexican food”, http://www.campusreform.org/?ID=6873.
} 
To some degree we have always had a variety of techniques by which we repress speech in America. But, even if the ideal of honest discourse has often been honored only in the breach, the intensity and scale of speech repression has grown to epic and constant proportions. ${ }^{11}$ Nicholas Sarkozy remarked after the first bombing attack on the Charlie Hebdo journal that: "If we no longer have the right to laugh at terrorists, what arms are citizens left with?" He added: "How is making fun of those who commit terrorist acts throwing oil on the fire?" ${ }_{12}$ Henryk Broder identified the strategy behind the use of violence and to this I would add other forms of assault such as lawsuits, calls for discharge from employment of those who offended a group, economic boycotts, and often libelous and anonymous on-line Internet attacks. ${ }^{13}$

\section{The "Fettering of the Collective Spirit"}

The Renaissance and the Enlightenment were intended to free us from centuries of darkness and ignorance in ways that allowed the full flourishing of humanity. Unfortunately it turns out that we are somewhat less as a species than hoped and considerably less interested in open-minded freedom of thought and expression. Albert Schweitzer argued decades ago: "The past has, no doubt, seen the struggle of the freethinking individual against the fettered spirit of a whole society, but the problem has never presented itself on the scale on which it does to-day, because the fettering of the collective spirit ... by modern organizations, [by] modern unreflectiveness, and [by] modern popular passions, is a phenomenon without precedent in history." ${ }^{14}$

If the iconic Albert Schweitzer described the situation accurately more than fifty years ago, it has only become far worse today. In part the decline is due to the emergence of the Internet and related communications technologies. Although they offer incredible tools for

\footnotetext{
${ }^{11}$ On this theme see, Diane Ravitch, The Language Police: How Pressure Groups Restrict What Students Learn (New York, Alfred A. Knopf 2003); and David E. Bernstein, You Can't Say That!: The Growing Threat to Civil Liberties from Antidiscrimination Laws (Washington, Cato Institute 2003). See also, Dawn C. Nunziato, "The Death of the Public Forum in Cyberspace," 20 Berkeley Technology L. J. 1115 (2005).

12 See, "Sarkozy backs Charlie Hebdo", The Guardian, 2/7/07.

${ }^{13}$ Henryk M. Broder, “Threaten One, Intimidate a Million”, Spiegel Online, 2/1/06, (visited 2/21/07).

${ }^{14}$ Quoted in Erich Fromm, The Sane Society 201, 202 (1955).
} 
the management and dissemination of knowledge, they have unfortunately bestowed power on fanatics and ideologues and in doing so opened an electronic "Pandora's Box" full of hate, vitriol and ignorance. A result has been the rapid fragmentation into aggressive actors and indignant cults. This has produced a social and political balkanization dominated by single-interest groups that are intent on achieving narrow agendas. These groups and political activists often operate without any willingness to consider how their interests fit within the essential dimensions of an overall community in which balance is necessary and compromise is not weakness but the "glue" that holds us together.

\section{“Who Speaks for the Cowboy?: A Few Examples of Speech Repression}

The Ayaan Hirsi Ali, Condoleeza Rice, Lawrence Summers and Clemson's “Maximum Mexican Day" reports offer some insight into what is occurring. Here are a few other examples of what I am talking about that demonstrate that what is occurring in the realms of symbolic and verbal expression aimed at controlling acceptable discourse goes well beyond these instances. The situation is worsening rather than improving.

- "Cowboy Up": At the University of Colorado students have been told not to wear "offensive" Halloween costumes. This includes cowboy and Indian "getups" and (apparently) anything involving a sombrero. The report states: "A university spokesman called cowboy costumes a 'crude stereotype."'15

- Some Cartoons Aren't Funny: When a Danish newspaper published cartoons that resulted in violent and deadly reactions in much of the Islamic world many Westerners educated in cultures that consider free speech as a central principle of democracy supported the publication. The Economist commented on the Cartoon Riots that: "Freedom of expression, including the freedom to poke fun at religion, is not just a hardwon human right but the defining freedom of liberal societies. When such a freedom comes under threat of violence, the job of governments should be to defend it without reservation.” ${ }^{16}$ In its unique way of protecting freedom of expression the U.S. State Department immediately announced it "was 'unacceptable' to incite religious hatred by publishing such pictures" and "Britain's foreign secretary, called their publication unnecessary, insensitive, disrespectful and wrong." ${ }^{17}$ The cartoonist remains under a death threat from Islamic extremists and is provided with round the clock security protection. I wonder if State Department spokesman and the UK's foreign secretary feel

\footnotetext{
15 Lucy Kinder, 24 Oct 2013.

16 "Cartoon wars," The Economist, supra n. at 9.

17 “Cartoon wars," The Economist, supra n. at 9. id.
} 
that a Muslim faction's setting off bombs and machine-gunning the editorial staff at the satirical French magazine Charlie Hebdo was "insensitive, disrespectful and wrong” or if the equation just flows in one direction.

- That Damn Rushdie Just won't Shut Up: The “insensitive” writer Salman Rushdie spent years in hiding after the Iranian Ayatollah Khomeini issued a fatwa calling for his death for writing The Satanic Verses. Rushdie more recently criticized the British government for failing to protect freedom of expression when it banned the staging of a play in the UK due to threats of violence from some fanatical Sikhs. "It's been horrifying to see the response," he said. "It is pretty terrible to hear government ministers expressing approval of the ban and failing to condemn the violence when they should be supporting freedom of expression,"' 18

- You Can Burn the Flag or Christian Bible, but the Qur'an is Off Limits: Rushdie presumably would not have voiced much support for US Supreme Court Justice Stephen Breyer's suggestion that burning a Qur'an in the United States could be an act not protected by the First Amendment. ${ }^{19}$ Apparently it is OK to burn our flag and the Bible in America but not the Qur'an.

- Leave Mmme. Bardot alone: Brigitte Bardot was charged with crimes by the French government due to a book she published. Bardot's "crime” was based on her criticism of Muslims in France and the suggestion that given the problems France was having with immigrants and the radically different cultures that they might not be the best of her country's recent imports. ${ }^{20}$ After authoring a book titled Un Cri dans le Silence (A Cry in the Silence) in which she criticized the Islamization of Europe, Bardot found herself prosecuted by French authorities for her critical remarks, convicted, and fined.

- Homophobia and Sexism: The French cabinet proposed to the legislature a new "gay insult" law that would impose heavy fines and criminal penalties for words that an American would consider tasteless but not consider actionable in terms of being a criminal act. ${ }^{21}$ Dominique Perben, the Justice Minister, asserts: "This law puts the fight against homophobia and sexism on the same footing, legally speaking, as the fight against racism and anti-semitism." ${ }^{22}$ Uttering an anti-gay insult in public including any remark "of a more general nature tending to denigrate homosexuals as a whole" could result in a fine of up to euro 22,500 and six months in jail. ${ }^{23}$

\footnotetext{
${ }^{18}$ See, Lee Glendinning, "Rushdie attacks closure of Sikh play,” The Guardian, Monday, December 272004.

19 “Justice Breyer Suggests That Burning a Quran Could be Like Shouting 'Fire' in a Crowded Theatre--Thus Not Protected by 1st Amendment," Wednesday, September 15, 2010, Chris Neefus. Muslims believe the Quran, in the original Arabic, to be the infallible "final revelation” of Allah to Mohammed. (CNSNews.com) - "Supreme Court Associate Justice Stephen Breyer said on Tuesday that globalization may change the way the First Amendment applies in the United States, and he suggested that Pastor Terry Jones’ proposed Quran-burning may or may not be protected under the First Amendment."

${ }^{20}$ Staff and agencies, "Bardot weeps over racism charges,” Friday, May 7, 2004, The Guardian [online]. See also, Polly Toynbee, "Get off your knees: Afraid of being labelled Islamophobic, the left has fallen into an embarrassed silence on religion. We must speak up,” Friday, June 11, 2004, The Guardian [online]; Jon Henley, “Jail sentence for sexist insults under new French law,” Thursday, June 24, 2004, The Guardian [online].

${ }^{21}$ Jon Henley “Jail sentence for sexist insults under new French law,” Thursday, June 24, 2004, The Guardian [online].

${ }^{2}$ Henly, id.

${ }^{23}$ Henly, id. France and Italy not the only countries where anti-vilification laws are being used to punish critics. Ben Knight, "Pastors refuse to apologise for vilification,” Australian Broadcasting Corporation, broadcast 6/22/05, http://www.abc.net.au/lateline/content/2005/s1398445.htm. visited 7/11/05.
} 
- The Irrational Indictment of Oriana Fallacci: Following 9/11 the late Italian journalist Oriana Fallaci authored several books relating to the collision between the Islamic and Western worlds. The books had sales of over a million copies, presumably indicating a substantial degree of public interest in the issues she addressed. In The Force of Reason Fallaci criticized Europeans for surrendering their culture to the "sons of Allah." Among her comments deemed offensive were: "Europe is no longer Europe, it is 'Eurabia,' a colony of Islam, where the Islamic invasion does not proceed only in a physical sense, but also in a mental and cultural sense. Servility to the invaders has poisoned democracy, with obvious consequences for the freedom of thought, and for the concept itself of liberty." ${ }^{24}$ Fallacci was charged with a criminal offense for her writing. Fallacci also warned: "You cannot survive if you do not know the past. We know why all the other civilizations have collapsed--from an excess of welfare, of richness, and from lack of morality, of spirituality." ... "The moment you give up your principles, and your values ... the moment you laugh at those principles, and those values, you are dead, your culture is dead, your civilization is dead. Period."

- How Did John Cleese Escape Prosecution: Given what has occurred with Bardot, Fallacci, and Dutch politician Geert Wilders who was unsuccessfully prosecuted by the Dutch government for comparing the Qur'an to Mein Kampf, I have absolutely no idea how Monty Python troupe actor and comedian John Cleese escaped prosecution for his comments that London isn't English anymore, adding: "'I'm not sure what's going on in Britain. Or, let me say this - I don't know what's going on in London, because London is no longer an English city. 'They said we were the most cosmopolitan city on Earth. But it doesn't feel English. 'I had a Californian friend come over two months ago, walk down the King's Road and say, "Where are all the English people?" 'I mean, I love having different cultures around. But when the parent culture kind of dissipates, you're left thinking, "Well, what's going on?"'25

- What's Your Problem, It's Only Prayer, For God's Sake: In the UK two boys were given detention after refusing to kneel down and 'pray to Allah' during a religious education lesson. ${ }^{26}$

- You Better Watch What You Write (Or Think): Federal agents in the US raided a reporter's home before dawn, ostensibly to check on weapons matters concerning her husband. In the process they seized the reporter's computer and notes and one agent made a comment that she knows the journalist has written articles critical of the government. ${ }^{27}$

\footnotetext{
${ }^{24}$ http://www.worldmagblog.com/blog/archives/015541.html. June 23, 2005/ visited 7/11/05. "How civilizations die," Posted by Veith at June 23, 2005 02:04 PM.

${ }^{25}$ Hugo Gye, "London is no longer an English city and that's how it got the Olympics, says John Cleese”, Daily Mail, 2 September 2011. http://www.dailymail.co.uk/news/article-2032956/John-Cleese-London-longer-Englishcity-thats-got-2012-Olympics.html\#ixzz2jVr7ID3c.

${ }^{26}$ Daily Mail Reporter, "Schoolboys punished with detention for refusing to kneel in class and pray to Allah”, July 4, 2008.

${ }^{27}$ Todd Starnes, "Federal agents' pre-dawn raid on reporter's home raises question,” Todd's American Dispatch, October 28, 2013, FoxNews.com. Starnes reports: “Audrey Hudson's husband had just left for work on August 6 when suddenly, her dog began barking. The nationally-known journalist walked over to the curtains and peeked
} 
- The "Al Capone" Tax Evasion Strategy Is a Tried and True Tactic: The somewhat "unique" Florida pastor, Terry Jones, who had threatened to burn a Qur'an was arrested on September 11, 2013 for the offense of transporting flammable materials without a permit. He was on his way to burn Qur'ans at a gathering to commemorate the 3,000 9/11 deaths.

- The "Heckler's Veto: A California school district sent three students home on Cinco de Mayo Day for wearing shirts depicting the American flag. A US Federal court judge dismissed the students' lawsuit but the US Court of Appeals reinstated it. The lower court judge noted that "our Constitution grants public school children only limited First Amendment rights when they enter the schoolhouse gates," while conceding this particular case has landed in "important legal territory." [UCLA] law professor and free speech expert Eugene Volokh calls such punishment a "heckler's veto." Volokh stated: "The fact of the matter is that these Americans were punished for wearing the American flag at an American school”. ${ }^{28}$

- Eat More Chik’n: “[R]emarks made by Chick-fil-A president Dan Cathy defending traditional marriage sparked controversy. Many Americans expressed support for his remarks and many others have expressed disdain. And all of that is fine, because in the United States people are supposed to be able to express their opinions. But in Chicago, Boston and other U.S. cities, vote-seeking politicians promised to keep Chick-fil-A stores from opening in their areas because Cathy does not support gay marriage. "When politicians threaten to ban a business from their cities just because the CEO does not hold the "politically correct" position on a social issue that is an attack on the freedom of speech of every American. You see, the truth is that the enforcers of political correctness in America are very "tolerant" except when somebody disagrees with them. .... They want to end debate on these social issues by shutting down the free speech of the opposition. In the end, if America continues to go down this path it will end up looking just like many of the other totalitarian regimes throughout history where free speech has been banned." 29

- Privatizing the Suppression of Free Speech: "The Christian Science Monitor has posted an interesting article entitled "Free Speech: What if Terry Jones Went to Sweden?" The author, Mike Sacks, compares the right to free speech in the United States with the more limited versions granted in other countries, particularly European ones. The CSM article, like so many others on this topic, ignores the fact that there is more than one way to skin a cat when suppressing freedom of speech. Formal criminal charges are not even the

outside to discover her Chesapeake Bay home was surrounded by law enforcement officers wearing full body armor. The phone rang. It was her husband. "I'm in the driveway," he said. "The police are here. Open the door." And so began Hudson's nightmare - held captive by armed agents of the U.S. Coast Guard, Maryland State Police and the Department of Homeland Security as they staged a pre-dawn raid in search of unregistered firearms and a "potato gun." "I think they found a great way to get into my house and get a hold of my confidential notes and go through every other file in my office." But instead of taking the potato gun, agents seized unrelated government documents and notes from the former Washington Times journalist.”

${ }^{28}$ Associated Press, “Appeals court to consider Calif. school's Cinco de Mayo American flag ban”, October 17, 2013. http://www.foxnews.com/us/2013/10/17/appeals-court-to-consider-calif-school-cinco-de-mayo-americanflag-ban/.

${ }^{29}$ Michael Snyder, “The Attack On Chick-Fil-A Is An Attack On The Freedom Of Speech Of Every American”, The American Dream, July 27, 2012. 
best method of enforcing silence on those whose expressions are unwelcome. There are numerous other techniques that can be brought to bear, and in a Western society such means are usually more effective than simple prosecution. In fact, the United States is often better than Europe at silencing dissent using alternative methods. Take, for example, the Danish Mohammed cartoons. Virtually no major American media outlet showed a single one of the cartoons. ... Yet numerous European newspapers - even in politically correct strongholds like Norway — printed at least some of the cartoons at one time or another." ${ }^{30}$

- No more Huckleberry Finn: One academic concerned about the rapidly increasing repression of our speech suggests that it is important not to allow discourse to be subordinated to repression and speech codes. He offers: "If this book, or that epithet, or that photograph, offends me, should we punish the offender? The question arises because everyone is offended by something, and offense hurts. But the absurdity of treating offended sensibilities as true injuries is shown by the converse fact: that anything will offend someone. None of us could teach anything if an offended student sufficed to stop us. No professor of literature could assign Salman Rushdie's Satanic Verses, or even Huckleberry Finn. No religion professor could assign any book of the Bible. No biology professor could teach evolution. Even if we could find pabulum that would pass the nooffense test, we would eviscerate our mission to fill our curriculum with it." ${ }_{31}$

\section{It Is Unwise to Grant Repressive Power Over Speech to Special Interests and the "Hyper-Sensitive"}

A driving force behind the increased use of law and the growing political power of identity collectives to silence critics is that we are no longer satisfied to look at the boors and bigots, judge them deficient and then go on with our lives. It is not enough for us. We think either that the people who would dare voice something that offends us ought to be made to shut up, or they should suffer significant consequences that teach them that there is a systemic penalty for what we see as their bigotry or insensitivity. This mindset challenges the core values of democracy. The First Amendment Center offers the position that:

An offended person's decision not to speak is hardly a reason to suppress the speech of others. Those who find an idea, epithet, literary work or

\footnotetext{
30 "Privatizing the Suppression of Free Speech", October 4, 2010, Gates of Vienna, http://gatesofvienna.blogspot.com/2010/10/privatizing-suppression-of-free-speech.html.

${ }^{31}$ Peter Suber, in "Unsimplifying Political Correctness: When the Right and Left are Right and Wrong", http://legacy.earlham.edu/ peters/writing/pc.htm.
} 
other form of expression offensive can oppose, counteract and perhaps refute it with further speech - not by banning the speech deemed to be offensive. As Justice Louis Brandeis said in a famous quote, 'If there be time to expose through discussion the falsehood and fallacies, to avert the evil by the processes of education, the remedy to be applied is more speech, not enforced silence.' 32

The power of the "anti-hate" and "insensitivity" strategies inherent in the movement to control our language is that accusation of being "phobic" or bigoted or a "hater" or "insensitive" are not disprovable. They produce an emotional response as if the targeted person was a rabid dog that ought to be "put down" or is afflicted with a communicable disease that requires perpetual quarantine. Such charges are used to sanction anyone who questions the motives or arguments of a special interest group. It takes a strong person to withstand the threat because many of the interest groups attack anything they consider inappropriate and do their best to figuratively eviscerate anyone who challenges their position. In instances such as the Cartoon Riots, death fatwas against Ayaan Hirsi Ali and Salman Rushdie, the murder of Piet van Gogh in Holland and killings of Christians in Pakistan for alleged acts of anti-Islamic heresy, the desire to destroy has proved entirely literal.

Or the situation may be one where the person unfortunate enough to be accused of having said something offensive, insulting or insensitive may simply be seen as being in the way of the accusers' "rightful" path to power. The adage, "all's fair in love or war" [at least in one direction] applies here and many of the ideologically driven identity groups see the struggles within modern society as a sort of guerrilla war where the end justifies nearly any strategy and tactic that might be required. This is why it is common for offended groups to seek contribution lists that can be used to identify people holding different views they then decide to attack and punish. This is a dismaying example of intolerance on the part of interests that gained a great deal by others' tolerance while demanding not only that their own beliefs and values be tolerated, but respected, which is a very different

\footnotetext{
${ }^{32}$ http://www.firstamendmentcenter.org/Speech/pubcollege/faqs.aspx?faq=all.
} 
thing. ${ }^{33}$ At the same time, the mask of anonymity granted by judicial interpretations of the First Amendment is frequently used by those on each side of a dispute to hide their own identities and avoid potential consequences for their own speech.

The "fighters" on either side who launch such verbal weapons really do not want reasoned dialogue as opposed to "put-downs" and gaining leverage through shaming and threats. It is all about political agendas and dominance of discourse as opposed to an actual "can we talk about this" interaction. Whatever is the case in a theocratic state such as the Ayatollahs' Iran or a dictatorial state such as Vladimir Putin's Russia, I argue that that in a legitimate democratic system people do not have the right to be free from insult. In Snyder v. Phelps (the Westboro Church case) the Supreme Court held that speech uttered on a public sidewalk about a public issue cannot create liability for the tort of emotional distress even if the speech is "outrageous" which nearly any reasonable person would conclude was the case in the specific situation.

At issue in the case was whether the First Amendment protected protests by public protestors at a funeral from being held liable in tort to people who would foreseeably be offended and emotionally harmed by the protestors' actions as they buried a loved one killed in the service of his country. Snyder involved a claim of the intentional infliction of emotional distress made by Albert Snyder, the father of a Marine, Matthew Snyder, who died in the Iraq War. The claim was made against the Phelps family, Fred Phelps, and Phelps' Westboro Baptist Church (WBC). The Court ruled 8-1 in favor of Phelps. The holding was that the speech related to a public issue and took place on a public sidewalk. ${ }^{34}$

From my personal point of view are the Westboro protesters unforgivably vile? Of course they are. Is what they do offensive? Yes. If they did it to me while I was burying my child

\footnotetext{
33 Karen Grigsby Bates, “Backers Of Calif. Gay Marriage Ban Face Backlash”, NPR, March 05, 2009; http://www.npr.org/templates/story/story.php?storyId=101460517. See also, Steven Greenhut, "California AG demands conservative group’s donor lists”, Dec 18, 2014, Human Events, http://humanevents.com/.

${ }^{34}$ Snyder v. Phelps, 562 U.S. 443 (2011).
} 
would I feel an intense and close to irresistible urge to take out a weapon and execute them en masse? You betcha'! But do I want the State "picking and choosing sides"? No. Do I value freedom of speech to the point that it seems clear the Court decided correctly in Snyder? Yes. Do I hate that fact? Yes. Do I still maintain that the Court's decision was absolutely vital in protecting free speech in our democracy and part of the price we must pay to be members of that political community? Absolutely. But Snyder is pretty much a "one-off" case where the protesters, vile and irrational, are in a strange way to be admired for their persistence in the face of the overwhelming revulsion and condemnation that faced the Westboro Church fanatics wherever they appeared. Few have the combination of courage and irrational commitment required to persist in the face of such condemnation and concerted opposition.

Does Snyder have implications for the numerous other situations in which speech is being intimidated and suppressed in the US? Not much. The reality is that other forms of speech repression have become so prevalent that Snyder will have little effect on how American culture operates either legally or through the privatization of speech intimidation and repression made possible by the frightening power of the Internet. The Internet is a powerful weapon in the hands of "no holds barred" special interest and activist groups. They are allowed to conceal their identities behind masks of anonymity from behind which they launch vicious attacks bordering on fanaticism and a kind of collective emotional disease. Anyone who disagrees with the agenda is fair game for reputational and career slaughter.

\section{Speech Suppression Through Law}

Enacting legal sanctions against what some are likely or even certain to consider insultwhether by statute, judicial interpretation or bureaucratic fiat--kills the discursive spirit of democracy. ${ }^{35}$ It becomes a situation in which potential speakers become risk averse because they do not want to face the vitriol automatically spewed by groups who feel their

\footnotetext{
${ }^{35}$ See, e.g., Polly Toynbee, "My right to offend a fool: Race and religion are different - which is why Islamophobia is a nonsense and religious hatred must not be outlawed," The Guardian [online], Friday June 10, 2005.
} 
agendas threatened or their moral positions criticized even though such reasoned challenges are considered intrinsic to the democratic process.

Guardian columnist Polly Toynbee captured the consequences of such speech restrictive laws during a time when the UK was considering an "anti-insult" law that was little more than a ban on criticism of religion. Toynbee observed: "Laws change cultural climates: it's what they are for. Religion will become out of bounds in many spheres. Schools, universities, the arts, broadcasting, will feel social pressures that induce self-censorship. A small example: if you wonder why there have been no penetrating exposes of cults like Scientology in recent years, it is because they have sued so often that the media caved in - fear of litigation outweighs the story. That is how the law cast its shadow." 36

The problem is that control of language for political advantage is about dominance by a group or faction seeking to advance a political agenda, not discourse. We see this in carefully designed "framings" such as "freedom of choice" v. "right to life". It arises in terms such as "homophobia", "sexism", "racism", "Islamophobia", and many other carefully chosen phrasings including "Lesbophobia" that I assume means fear of lesbians. After all, if someone is a "phobe" of one sort or another it is intended by the groups creating the label to be a sign of prejudice, irrationality, dark motivations or worse. Being labeled as such is something from which we emotionally recoil. We now live in an historical moment that has so many linguistic taboos that we walk through a verbal "minefield" if we attempt to have honest discussion in any situation of conflicted politicized dispute.

In the context of immigration, for example, there has been a deliberate effort to recast or "reframe" the meaning of law breaking from "illegal" aliens to "undocumented" aliens. The problem is that most of the people in question are undocumented because they committed the illegal acts of entering or remaining in the US in violation of the nation's immigration laws. Golly! When I break the law it is called an illegal act. When others who are part of an organized political movement favored by the government in power or a large scale and

\footnotetext{
${ }^{36}$ Polly Toynbee, "My right to offend a fool," id, The Guardian [online], June 10, 2005.
} 
aggressive pro-immigration movement do it, it is "reframed" to alter its impact and perception. The mantra of the burgeoning immigration legalization movement is now focused on asserting it is only fair and just that the "undocumented" be allowed to "come out of the shadows". This ignores the fact that it was their own illegal actions that placed them in that situation by deliberately entering a country in violation of its laws.

I don't want anyone to think I am singling out Liberal, Progressive or Leftist actors and leaving the Right of Center unscathed. Everyone is engaging in linguistic behavior that can only be described as demagoguery and propaganda. On the Right side of the political equation the ability to "frame" extremely complex situations as matters of "National Security", "War on Terror", the imperatives of the "Market Economy", "Capitalism" or even "Democracy" [in Kuwait, Libya, Syria or Iraq] manipulates and is intended to manipulate our thought processes and judgment.

Dominic Raab, who has an extensive background in the UK's Foreign Office, explains his concern as one where: "any democratic government must be accountable to their citizens, particularly if they impinge on their citizens' freedoms in the necessary pursuit of security. In recent years, UK surveillance of its citizens has increased exponentially, and the legal basis has sometimes, and now regularly, appeared strained at best. Oversight is frayed and legitimate debate is at risk of being drowned out by frankly untested assertions of national security." ${ }^{37}$

This use of "frames" to shut down criticism of one's actions occurs to the point that it is difficult to sort out the real and concrete issues from interests that are served by the way in which matters are framed. The result is a flood of propaganda-driven "missile strikes" utilizing words and symbols designed to penetrate us on a deep emotional level while

\footnotetext{
${ }^{37}$ On this topic see, Dominic Raab, “GCHQ leaks: we can't just guillotine all debate with the phrase 'national security'”, theguardian.com, November 1, 2013. http://www.theguardian.com/commentisfree/2013/nov/01/gchqnational-security-intelligence-dominic-raab.
} 
bypassing conscious thought. ${ }^{38}$ At this point we have devolved to the level of marionettes whose strings are being pulled by verbal puppet masters in a series of political plays. The messages we hear are slogans that act as our "strings" and we dance to the music of snake charmers intent on controlling our hearts and minds to advance their own agendas.

\section{Back to the Responsibilities of Universities}

In theory and rhetoric we can argue that we are responsible for using our universities to educate our students in the importance of free and open thought and questioning. Unfortunately, the sad fact is that many of our schools and universities such as Brandeis, Rutgers and Clemson to name several, have fallen prey to educating based on such "mantras" that contradict and undermine the core of their missions. The suppression of thought and intellectual discourse is once again rising throughout higher education. This means that we aren't educating our youth or teachers into critical and honest modes of thought, judgment and communication.

Our society is increasingly one in which our educational programs are becoming progressively more superficial and anti-intellectual in the sense they do not inspire open minded and critical thinking. The reality is that in far too many instances critical thinking and the challenging of authoritarian assertions are punished rather than nurtured. A caustic critique of the university in America is offered by John Diggins who concludes: "Today the Left's life-support system is the university, which has produced a "new class" credentialed with advanced degrees and enjoying elite status, what Thorstein Veblen-whose Higher Learning in America bears the subtitle "A Study in Total Depravity"-would probably have called "The Leisure of the Theory Class." " 39

\footnotetext{
${ }^{38}$ Raab, $i d$, concludes his analysis with the urging: "Above all, we must take this debate forward, away from the polarised and untested assertions on either side, and place the work of those who would protect us on a firmer footing. Karl Popper said: "We need to pursue our security in a way that respects our freedoms, limits incursions to genuine cases of national security and does so under a regime that commands the rule of law."

${ }^{39}$ John Patrick Diggins, The Rise and Fall of the American Left 290 (W.W. Norton \& Co., New York and London, 1992.
} 
At this point my fear is that most universities are largely incapable of facilitating and instilling open minded thought and critique, in large part because many of the faculty members in areas such as the social and political sciences [as well as law] have become ideologues conforming to the assertions and political agendas of the groups to which they have pledged allegiance. ${ }^{40}$ Jacques Ellul observed: "modern man is beset by anxiety and a feeling of insecurity. He tries to adapt to changes he cannot comprehend. The conflict of propaganda takes the place of the debate of ideas." ${ }^{41}$

Given the intensity with which many university faculty members protect their views, those who do not share those dominant agendas and belief systems are afraid of the repercussions that will occur if they speak their minds and challenge the controlling orthodoxy. Peter Berger has suggested one of the reasons an orthodox possesses such power is that: Berger observes: "[M]ost of the time we ourselves desire just that which society expects of us. We want to obey the rules. We want the parts that society has assigned to us." ${ }^{42}$ Berger adds: "Institutions carry within them a principle of inertia, perhaps founded ultimately on the hard rock of human stupidity." 43

This desire to fit in, not "rock the boat" and make enemies often means that nascent scholars rite about "safe" or non-controversial topics and avoid those that can destroy their careers. In that context "non-controversial" does not mean within the general society but that which conforms to and is accepted by the agendas of those who have career determinative power over the scholar's future within the university. This means it is safer to join a dominant orthodoxy rather than challenge it. After the scholar receives tenure and long-term job security the career track has already been established with career rewards and opportunities associated with the earlier developments. A consequence is that those who should be acting as independent voices fulfilling their responsibility as intellectual leaders are instead followers who are "playing it safe”. A tragic result is that as a culture we are devolving in terms of our ability to think, analyze, discuss and recognize the possibility of merit in others' positions even if they do not

\footnotetext{
${ }^{40}$ C. Axelrod, Studies in Intellectual Breakthrough, Freud, Simmel, Buber 2,3 (1979). See also, David Barnhizer, "Truth or Consequences in Legal Scholarship?” 33 Hofstra L. Rev. (2005), and David Barnhizer, “A Chilling of Discourse”, 50 St. Louis Univ. L. Rev. 595 (2006).

41 Jacques Ellul, The Technological Society, at vii (1964).

42 Peter Berger, Invitation to Sociology: A Humanistic Perspective 93 (Doubleday \& Co. 1963).

${ }^{43}$ Berger, id, at 68.
} 
conform to our own. This makes discussion, negotiation and compromise nearly impossible.

\section{The ACLU's Position on “Hate Speech"}

The analysis presented here clearly is intended to support our traditional understanding of the vital role of free speech in a democracy, including in educational institutions. This position is represented well in the analysis of the need to protect free speech from the rising tide of actions aimed at suppressing our ability to communicate or to pontificate even if what we say is mean-spirited, hurts someone's feelings, offends or is simply stupid. The ACLU argues:

In recent years, a rise in verbal abuse and violence directed at people of color, lesbians and gay men, and other historically persecuted groups has plagued the United States. Among the settings of these expressions of intolerance are college and university campuses.... Many universities, under pressure to respond to the concerns of those who are the objects of hate, have adopted codes or policies prohibiting speech that offends any group based on race, gender, ethnicity, religion or sexual orientation.

That's the wrong response, well-meaning or not. The First Amendment to the United States Constitution protects speech no matter how offensive its content. Speech codes adopted by government-financed state colleges and universities amount to government censorship, in violation of the Constitution. And the ACLU believes that all campuses should adhere to First Amendment principles because academic freedom is a bedrock of education in a free society. ${ }^{44}$

Several examples, and there are far too many available, include death threats to "a woman delegate to the German Bundestag" for "suggesting that Muslim immigrants remove their headscarves". ${ }^{45}$ France, like Germany, Italy, Greece, the Netherlands, the UK and Scandinavian countries, is having a difficult time with its clash of cultures. These not only include the annual riots in Parisian suburbs by alienated Muslim youth, the Charlie Hebdo bombing and later massacre, arson and murders as well as death threats to a French high

\footnotetext{
44 ACLU, “Hate Speech on Campus”, https://www.aclu.org/hate-speech-campus.

45 See, Richard Wolin, “Veiled Intolerance,” The Nation, April 9, 2007.
} 
school philosophy teacher for writing an article in Le Figaro comparing Islam unfavorably with Christianity. ${ }^{46}$

${ }^{46}$ On this particular controversy, see, Christian Delacampagne, “The Redeker Affair”, Commentarymagazine.com, January 2007 Issue. 